\title{
Significance of Cross-contamination on Bacteriological Quality of Black Tiger Shrimp (Penaeus monodon Fabricius 1798) for Export Trade Produced in Fish Processing Plant
}

\author{
Basudev Mandal', Sourabh Kumar Dubey ${ }^{2 *}$, Dona Bhattacharya ${ }^{1}$ and Bimal Kinkar Chand ${ }^{3}$ \\ ${ }^{1}$ Department of Aquaculture Management and Technology, Vidyasagar University, Midnapore, West Bengal-721102, India \\ ${ }^{2}$ Department of Aquatic Environment Management, Faculty of Fishery Sciences, West Bengal University of Animal and Fishery Sciences, Kolkata-700094, India
} ${ }^{3}$ Directorate of Research, Extension and Farms, West Bengal University of Animal and Fishery Sciences, Kolkata-700037, India Sciences, Kolkata-700037, India

\begin{abstract}
In this study, bacteriological quality of raw and processed Penaeus monodon produced for export trade from preprocessing, processing area and cross-contaminated sample was analysed in terms of total plate count (TPC), Vibrio cholerae, Escherichia coli, Staphylococcus aureus, Salmonella spp and Listeria monocytogenes from a HACCP (Hazard Analysis Critical Control Points) approved processing plant. In all cases bacterial loads were highest in crosscontaminated sample than the pre-processing and processing area. E. coli was present in cross-contaminated raw and processed sample; however V. cholerae, S. aureus, Salmonella spp and L. monocytogenes were not detected in any case. In pre-processing, processing and cross-contaminated samples, the TPC value was not exceeding the standard limits as per ICMSF (International Commission on Microbiological Specifications for Foods Standards) and EIC (Export Inspection Council) standard. Another side of the present work indicated that, microbial analysis of all the samples obtained from processing area were within the permissible limits. This study clearly indicated that maximum microbial load in cross-contaminated condition due to transfer of place, shifting of equipments, products etc. The present microbiological survey revealed that there is an urgent need for considerable improvement in the bacteriological quality of products and it should be free from cross-contamination. Strict observance to CGMPs (Current Good Manufacturing Practice) and HACCP plan can greatly improve the product quality and reduce the risk of cross-contamination.
\end{abstract}

Keywords: Cross-contamination; Total Plate Count (TPC); Penaeus monodon; Escherichia coli; Salmonella; Staphylococcus; Listeria monocytogenes

\section{Introduction}

Shrimp is the major value added exported fishery product of India [1]. Southeast Asia continued to be the largest buyer of Indian marine products with a share of $25.75 \%$ in US\$ realization and $39.58 \%$ in quantity. Exports to Southeast Asia have shown a growth of $43.19 \%$ in quantity and $95.99 \%$ in US\$ realization. European Union ranks second in terms of frozen shrimp export with a share of $22.02 \%$, followed by USA $19.17 \%$, Japan 14.09\%, China 7.06\%, Middle East $4.39 \%$ and other countries $7.51 \%$ [2]. In Indian shrimp culture scenario, West Bengal is the second dominant shrimp producing state across its 158 $\mathrm{km}$ coastline [1]. The dominant species of shrimp, Penaeus monodon Fabricius 1798 (black tiger) are extensively cultured in the coastal area of West Bengal due to its unique taste, high unit value and everexpanding export demand in the global market.

Most of the farm-raised products of shrimps are being processed as either block frozen or individually quick frozen (IQF) for export to various countries in Middle East Asia, Europe, Japan, and USA [3]. Frozen shrimp in India continued to be the major export item accounting for $51.35 \%$ of the total foreign exchange earnings. Shrimp exports from India during 2010-2011 increased by $17.67 \%, 34.77 \%$ and $32.98 \%$ in quantity, Indian rupee value and US\$ value respectively than the previous year [2]. In past decades, the frozen shrimp exported from India had faced many problems such as high bacteriological count in the cooked and peeled frozen shrimps, as well as the presence of other pathogenic bacteria such as Salmonella [3]. Food security is a complex issue, where animal proteins such as fish and fishery products are generally regarded as high risk commodity with respect to pathogen contamination, presence of natural toxins and adulterants [4]. Moreover coliforms, especially Escherichia coli are the most alarming concern in all types of food products as their presence reflects the unhygienic handling during production process, improper storage conditions and post-process contamination [5-7]. It is important to note that cross-contamination of pathogenic bacteria in the finished shrimp products is generally introduced by human contact in the various steps of the process flow. The problem of cross-contamination in relation to potential transmission of pathogens to food is a serious issue in food processing and allied industries. The possible route of pathogenic bacterial contamination in shrimp products takes place either by direct contact with contaminated containers or through airborne particles. Some potential pathogenic bacteria are attached to the surfaces of the products as their predominant form of survival in nature and man-made ecosystems [8]. Several studies indicated that various bacteria including Escherichia coli, Staphylococcus aureus and Salmonella spp., survive on hands, cloths, utensils etc. after initial contact with the microorganisms [9-11].

Augmented import of seafood from developing countries resulted in the acceptance of international guidelines for food processing

${ }^{*}$ Corresponding author: S. K. Dubey, Faculty of Fishery Sciences, Department of Aquatic Environment Management, West Bengal University of Animal and Fishery Sciences, Kolkata-700094, India, Tel: +91 9830094171; E-mail: sourabhkumardb@gmail.com

Received June 19, 2015; Accepted August 27, 2015; Published December 15, 2015

Citation: Mandal B, Dubey SK, Bhattacharya D, Chand BK (2015) Significance of Cross-contamination on Bacteriological Quality of Black Tiger Shrimp (Penaeus monodon Fabricius 1798) for Export Trade Produced in Fish Processing Plant. J Aquac Res Development 6: 381. doi:10.4172/2155-9546.1000381

Copyright: ( 92015 Mandal B, et al. This is an open-access article distributed under the terms of the Creative Commons Attribution License, which permits unrestricted use, distribution, and reproduction in any medium, provided the original author and source are credited. 
Citation: Mandal B, Dubey SK, Bhattacharya D, Chand BK (2015) Significance of Cross-contamination on Bacteriological Quality of Black Tiger Shrimp (Penaeus monodon Fabricius 1798) for Export Trade Produced in Fish Processing Plant. J Aquac Res Development 6: 381. doi:10.4172/2155-9546.1000381

Page 2 of 5

such as Hazard Analysis Critical Control Points (HACCP) and European Union (EU) guidelines. In an attempt to control the microbial contamination of foods, various international agencies have recommended microbiological criteria for assessing the effectiveness of HACCP program [12]. If coliforms were effectively destroyed at the pasteurizing step, still there was a possibility to detect their presence in the cooked products. These cases were also noticed when Good Management Practice (GMP) and HACCP programs are implemented to access best hygienic conditions for human consumption. As the bacterial contamination come from various sources in the processing work flow, it is extremely important to identify the possible route of cross-contamination to establish effective control process of the bacterial contamination and strengthens the GMP and HACCP programs [13]. There are some reports on the bacteriological assessment of frozen raw, processed IQF and ready to eat shrimps produced from processing plant in India [3,14-16]. Rao et al. [17] studied the seasonal variations in the supply of raw materials at processing plants located in Cochin, Veraval and Kakinada in India. Iyer et al. [18] observed that bacterial content and handling of raw materials influence the bacteriological quality of frozen shrimps. Reilly et al. [19] reported microbiological changes of insufficiently iced and improperly stored shrimps at higher temperatures. Zuberi and Qadri [20] showed the important role of microorganisms in the deterioration of shrimp quality. Jeyasekaran et al. [21] reported the incidence of Listeria monocytogenes in seafood landed at the Mangalore coast of India. However, there are no such studies on differences of bacteriological load in the shrimp products before and after the food processing work flow. In continuation to the fact, the main objective of this study is designed to access the bacteriological quality of various processing steps, raw and processed black tiger shrimp in a processing plant following the HACCP guidelines.

\section{Materials and Methods}

\section{Study area and sampling design}

The experimental work was carried out in a processing plant located at East Kolkata Township ( $22^{\circ} 30^{\prime} 48.07^{\prime \prime} \mathrm{N}$ and $\left.88^{\circ} 24^{\prime} 06.43^{\prime \prime} \mathrm{E}\right)$, West Bengal, India with an approved HACCP plan. The processing plant has been regularly monitored and verified by respective competent authority.

Samples ( $\mathrm{N}=24$; three samples from eight treatments) were taken for microbiological evaluation such as total plate count (TPC), presence of $V$. cholerae, E. coli, S. aureus, Salmonella spp and $L$. monocytogenes in order to access the bacteriological quality of crosscontaminated condition and also the effectiveness of HACCP program. All samples were collected aseptically from pre-processing and processing areas according to the recommendation of USFDA [22]. Cross-contaminations of equipments were established by transferring them from processing to pre-processing areas at considerable distance and in direct contact with contaminated surfaces. Water and ice were also moved from processing to pre-processing areas and were placed in contaminated surface for long duration. The distance from preprocessing and processing area of the study design was about 115 meter. Bacteriological analysis was undertaken from three important steps of the process flow viz., i) receiving table, panning crate (a metal container or tray) and workers' hands ii) water and ice sample; and iii) head on black tiger shrimp (HOBT; shrimp with whole body parts), headless black tiger shrimp (HLBT; shrimp without head) and processed shrimp product from pre-processing and processing areas after cross-contamination.

\section{Bacteriological procedures}

The frozen samples were thawed before analysis by overnight storage at $5^{\circ} \mathrm{C}$ in a refrigerator. After that total plate count (TPC), detection of food borne pathogenic bacteria such as V. cholerae, E. coli, $S$. aureus, Salmonella spp and L. monocytogenes were undertaken as part of this study as per the instruction mentioned in Bacteriological Analytical Manual of Food and Drug Administration [22]. For swab test, solutions of peptone $\left(1 \mathrm{~g} \mathrm{~L}^{-1}\right)$ and sodium chloride $\left(8.5 \mathrm{~g} \mathrm{~L}^{-1}\right)$ were prepared. The solutions were stored in bottles and were sterilized for 15 minutes at $121^{\circ} \mathrm{C}$. Tryptone glucose beef extract (TGBE) agar (HiMedia, Mumbai) was used for the estimation of TPC after incubation at $35^{\circ} \mathrm{C}$ for $48 \mathrm{~h}$. For estimation of E. coli, Tergitol-7 agar (HiMedia, Mumbai) and Macconkey agar (HiMedia, Mumbai) were used as selective media and typical E. coli-like colonies were confirmed by IMViC test (Indole test, Methyl red test, Voges-Proskauer test, Citrate utilization test). Thiosulfate citrate bile salts sucrose (TCBS) agar (HiMedia, Mumbai) was used to evaluate the presence of $V$. cholerae after incubation of at $37^{\circ} \mathrm{C}$ for $24 \mathrm{~h}$ in alkaline peptone water (APW). For S. aureus, Baird parker agar (BP) (HiMedia, Mumbai) was used at $35^{\circ} \mathrm{C}$ for $48 \mathrm{~h}$. Typical colonies were confirmed using tube coagulase test [22]. For Salmonella detection, RappaportVassilliadis (RV) broth (HiMedia, Mumbai) and tetrathionate broth (TTB) (HiMedia, Mumbai) were used for selective enrichment after pre-enrichment in lactose broth. Selective media used were xylose lysine deoxycholate (XLD) agar, bismuth sulphite agar (BSA), and hektoen enteric agar (HEA) (HiMedia, Mumbai). For detection of L. monocytogens, Listeria enrichment broth (BLEB) (HiMedia, Mumbai) was used after pre-enriched at $30^{\circ} \mathrm{C}$ for $4 \mathrm{~h} \mathrm{[22].}$

\section{Statistical analysis}

The data obtained in the present investigations were subjected to one-way Analysis of Variance (ANOVA) using statistical software Medcalc $c^{\oplus}$ version 12.7.0. (MedCalc Software bvba, Ostend, Belgium). Tukey's (HSD) test was used to determine the differences among the means. Significant differences are stated at $\mathrm{P}<0.01$ level.

\section{Results}

Microbial analysis to determine the bacterial load in receiving table, panning crate and workers' hands before and after cross-contamination

Total plate count values of all cases were found to be significantly much higher $(P<0.01)$ in cross-contaminated samples than in preprocessing and processing areas. After cross-contamination, the TPC value was found to be highest $(P<0.01)$ in panning crates $\left(394.66 \pm 90.38 \mathrm{cfu} \mathrm{sq}^{-1}\right)$ followed by worker's hands $(273.33$

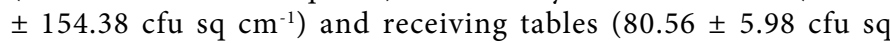
$\mathrm{cm}^{-1}$ ) respectively. In pre-processing areas, the TPC was highest in panning crates $\left(61.33 \pm 11.23 \mathrm{cfu} \mathrm{sq} \mathrm{cm}^{-1}\right)$ followed by receiving tables $\left(60.66 \pm 8.50 \mathrm{cfu} \mathrm{sq} \mathrm{cm}^{-1}\right)$ and workers' hands $(48.33 \pm 9.29$ cfu sq $\mathrm{cm}^{-1}$ ) respectively. In processing areas the lowest TPC was observed in receiving tables $\left(4.33 \pm 2.51 \mathrm{cfu} \mathrm{sq}^{-1}\right)$ followed by

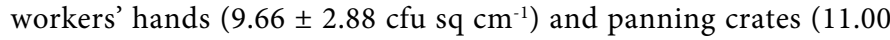

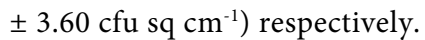

\section{Microbial analysis of water and ice samples before and after cross contamination}

$V$. cholerae was not detected in all the samples and E. coli were positive in cross-contaminated samples. High TPC values were observed $(P<0.01)$ in cross-contaminated water and ice samples than 
Citation: Mandal B, Dubey SK, Bhattacharya D, Chand BK (2015) Significance of Cross-contamination on Bacteriological Quality of Black Tiger Shrimp (Penaeus monodon Fabricius 1798) for Export Trade Produced in Fish Processing Plant. J Aquac Res Development 6: 381. doi:10.4172/2155-9546.1000381

Page 3 of 5

samples from pre-processing and processing areas, such as $122.50 \pm$ $25.35 \mathrm{cfu} \mathrm{ml}^{-1}$ and $271.66 \pm 53.79 \mathrm{cfu} \mathrm{ml}^{-1}$ respectively. Bacterial load in water samples from pre-processing and processing areas was 15.33 $\pm 6.02 \mathrm{cfu} \mathrm{ml}^{-1}$ and $7.66 \pm 5.50 \mathrm{cfu} \mathrm{ml}^{-1}$ respectively. In ice sample, TPC was lowest in processing area $\left(12.33 \pm 6.02 \mathrm{cfu} \mathrm{ml}^{-1}\right)$ followed by preprocessing area $\left(16.33 \pm 3.78 \mathrm{cfu} \mathrm{ml}^{-1}\right)$ but did not differ significantly $(P>0.01)$. E. coli in cross contaminated water and ice sample was $17.0 \mathrm{cfu} \mathrm{ml}^{-1}$ and $19.0 \mathrm{cfu} \mathrm{ml}^{-1}$ respectively. However, E. coli were not detected in samples collected from pre-processing and processing area.

\section{Microbial analysis of HOBT, HLBT and processed products before and after cross-contamination}

The TPC was significantly maximum $(P<0.01)$ in all crosscontaminated samples when compared to pre-processing and processing areas. After cross contamination, the TPC value was significantly higher $(P<0.01)$ in processed products $\left(5.1 \times 10^{4} \mathrm{cfu} \mathrm{g}^{-1}\right)$ followed by HLBT $(4.8$ $\left.\times 10^{4} \mathrm{cfu} \mathrm{g}^{-1}\right)$ and HBOT $\left(4.5 \times 10^{4} \mathrm{cfu} \mathrm{g}^{-1}\right)$ respectively. In the preprocessing area, the TPC of HOBT, HLBT and processed samples were $3.5 \times 10^{4} \mathrm{cfu} \mathrm{g}^{-1}, 3.8 \times 10^{4} \mathrm{cfu} \mathrm{g}^{-1}$ and $4.9 \times 10^{4} \mathrm{cfu} \mathrm{g}^{-1}$ respectively. In the processing area, the TPC of HOBT, HLBT and processed sample was $1.6 \times 10^{4} \mathrm{cfu} \mathrm{g}^{-1}, 2.9 \times 10^{4} \mathrm{cfu} \mathrm{g}^{-1}$ and $3.1 \times 10^{4} \mathrm{cfu} \mathrm{g}^{-1}$ respectively. E. coli was present in all cross- contaminated samples, however $V$. cholerae, $S$. aureus, Salmonella spp and $L$. monocytogenes were not detected in HOBT, HLBT and processed samples from pre-processing, processing areas and cross contaminated samples. E. coli in cross contaminated HOBT, HLBT and processed samples were $3.0 \mathrm{cfu} \mathrm{g}^{-1}, 7.0 \mathrm{cfu} \mathrm{g}^{-1}$ and 11 cfu g $^{-1}$ respectively.

\section{Discussion}

Pérez-Rodríguez et al. [23] defined cross-contamination as "a general term which refers to the transfer, direct or indirect, of bacteria or virus from a contaminated product to a non-contaminated product". According to the World Health Organization [24], 25\% of foodborne outbreaks are closely associated with cross-contamination events involving scarce hygiene practices, contaminated equipment, and contamination via food handlers, processing, or inadequate storage. Chen et al. [25] demonstrated that bacterial transfer rates varied by more than five orders of magnitude depending on the nature of the surfaces involved in the cross-contamination. According to him a transfer rate of $100 \%$ was identified as the maximum value, although in some cases it was found that the recipients demonstrated higher numbers of microbial load than the contributor of contamination. Our study clearly indicated that maximum microbial load in crosscontaminated condition due to transfer or shifting of the place, equipments and products from the concerned place to another places.

The total bacterial load in all the evaluated samples was high in cross-contaminated condition. In pre-processing, processing and cross-contaminated samples, the value was not exceeding $10^{4} \mathrm{cfu}$ $\mathrm{g}^{-1}$, which is lower than the standard limits of $5 \times 10^{5} \mathrm{cfu} \mathrm{g}^{-1}$ as per International Commission on Microbiological Specifications for Foods Standards $[26,27]$ and Export Inspection Council, India [28,29]. Most of the previous studies indicated that bacterial load in fresh tropical shrimps ranged from $10^{3}$ to $10^{5} \mathrm{cfu} \mathrm{g}^{-1}[20,30-34]$.

The presence of $E$. coli in ready-to-eat foods is undesirable because it indicates poor hygienic conditions during processing. In the present study, E. coli were positive in cross- contaminated samples. In water and ice samples E. coli levels exceed ICMSF standards but within marginally acceptable range, however in HOBT, HLBT and processed shrimp products $E$. coli was within ICMSF acceptable limits i.e., 11 cfu $\mathrm{g}^{-1}$. Ideally $E$. coli should not be detected and as such a level of $<3 \mathrm{~g}^{-1}$ has been given as the satisfactory criteria for this organism. Levels exceeding $100 \mathrm{~g}^{-1}$ are unacceptable and indicate a level of contamination [27]. This finding substantiates with the study of Iyer and Shrivastava [14] and Antony et al. [35]. Jeyasekaran et al. [36] reported that E. coli in shrimp ranged from 0.6 to $240 \mathrm{cfu} \mathrm{g}^{-1}$. Iyer et al. [18] also stated that season plays a role in controlling the bacterial quality of raw shrimps and observed that the bacterial counts were higher in certain specific seasons.

$V$. cholerae, S. aureus, Salmonella spp and L. monocytogenes were below detection limit in all the samples. Varma et al. [37] documented that out of the 7,238 tested shrimps, $V$. cholerae was present in only one raw shrimp. Antony et al. [35] also found similar results. ICMSF acceptable range of $S$. aureus was $<1.0 \times 10^{3} \mathrm{cfu} \mathrm{g}^{-1}$, however, levels of $\geq 10^{4} \mathrm{cfu} \mathrm{g}^{-1}$ are considered hazardous as foods with this level of contamination may result in food borne illness if consumed. Hatha et al. [3] detected Staphylococci less than 1\% of the IQF shrimp samples. Ready-to-eat foods should be free of Salmonella as consumption of food containing this pathogen indicates poor food preparation and handling practices or cross-contamination which may result in food borne illness. Their presence in high numbers $\left(>10^{4} \mathrm{~g}^{-1}\right)$ in ready-toeat foods indicates that an unacceptable level of contamination has occurred. Consistent with the present study, Chen et al. [38] while analyzing bacteriological quality of shrimp, did not find Salmonella and Antony et al. [35] also observed similar findings. In Thailand, Dalsgaard et al. [39] also reported that Salmonella was not detected from shrimps. However, there were very few reports on the incidence of Salmonella in fish and fishery products in India [40]. Bhaskar et al. [41] reported the incidence of Salmonella from aquacultured shrimps. Food under refrigeration should be free from L. monocytogenes However levels of $10^{2} \mathrm{cfu} \mathrm{g}^{-1}$ indicate a failure with food handling controls and are considered a public health risk [42]. The present study is well supported by earlier studies of Manoj et al. [43], Kamat and Nair [44], Antony et al. [35] and Prabakaran et al. [16]. However, Jeyasekaran et al. [21] reported the incidence of L. monocytogenes in raw shrimps. As humans are the major source of contamination in the processing environment [45], good private hygiene and adherence to GMPs are a must to control contamination. Wearing of nose-mouth cover and periodical dipping of workers' hands in chlorinated water must be strictly followed in the processing unit [3].

The present study indicated that microbial analyses of all the samples obtained from the processing areas were within the safe limits suggested in the guidelines by competent authority [26-28] and these values were far lower than pre-processing areas. This finding reveals that the adherence to Current Good Manufacturing Practice (CGMPs) and HACCP plan greatly enhances the quality of food products in the processing plants. The sanitary conditions of seafood processing plant are also associated with the microbial quality of finished products $[46,47]$.

Though raw shrimps were procured exclusively from farms, the chances of natural contamination were expected in case of samples from polluted coastal waters [48]. However, the raw material could pick up microbial load during transportation and storage. Excellent temperature control of the raw material (less than $5^{\circ} \mathrm{C}$ ) during preprocessing might be able to control the multiplication of mesophilic microflora present in the raw material [3].

\section{Conclusion}

The risk of food-borne infection associated with crosscontamination depends on two factors: the level of contamination on the surfaces and the probability of its transfer to the foods being consumed [49]. The present microbiological survey revealed that there 
Citation: Mandal B, Dubey SK, Bhattacharya D, Chand BK (2015) Significance of Cross-contamination on Bacteriological Quality of Black Tiger Shrimp (Penaeus monodon Fabricius 1798) for Export Trade Produced in Fish Processing Plant. J Aquac Res Development 6: 381. doi:10.4172/2155-9546.1000381

is an urgent need for considerable improvement in the bacteriological quality of products and it should be free from cross-contamination. Strict adherence to CGMPs and HACCP plan can greatly augment the product quality and minimize the risk of cross-contamination. The processing plants should take paramount care while collecting raw specimens to produce uniformly high quality product. Prior to food preparation, all workers' hands should be free of all test microorganisms and changing of equipments from low risk zone to high risk zone should be avoided. Regular training programs should be organized for processing workers for effective implementation of HACCP programme and also to meet the requirements of European Commission and the other international food regulating bodies. Further studies on quantifying the cross-contamination risk associated with the various steps in the food preparation process can provide a scientific basis for risk management efforts in shrimp processing industries.

\section{Acknowledgments}

The authors are grateful to the Plant in-Charge of IFB Agro Industries Limited, Kolkata for their laboratory facilities and man power support. Dubey is also grateful to Prof. Trivedi, Head, Department of Aquatic Environment Management, Faculty of Fishery Sciences, West Bengal University of Animal and Fishery Sciences, Kolkata for his constant encouragement and permission for the study. The authors are also indebted to anonymous reviewers for their constructive comments.

\section{References}

1. Mandal B, Dubey SK (2015) Present status and prospects of black tiger shrimp farming: A case study in maritime state of West Bengal, India. In: Gupta VK, Verma AK, Singh GD (Eds.). Perspectives in Animal Ecology and Reproduction. Daya Publishing House, New Delhi, India.

2. Marine Products Export Development Authority (2012) News Letter, Kochi, Kerala, India.

3. Hata AAM, Maqbool TK, Kumar SS (2003) Microbial quality of shrimp products of export trade produced from aquaculture shrimp. International Journal of Food Microbiology 82: 213-221.

4. Yousuf AHM, Ahmed MK, Yeasmin S, Ahsan N, Rahman MM, et al. (2008) Prevalence of Microbial Load in Shrimp, Penaeus monodon and Prawn, Macrobrachium rosenbergii from Bangladesh. World Journal of Agricultural Sciences 4: 852-855.

5. Blood RM, Curtis GDW (1995) Media for total Enterobacteriaceae, coliforms and E. coli. International Journal of Food Microbiology 26: 93-115.

6. De Sousa GB, Tamagnini LM, Olmos PD, Gonzalez RD (2002) Microbia enumeration in ready-to-eat foods and their relationship to good manufacturing practice. Journal of Food Safety 22: 27-38.

7. Gonzalez RD, Tamagnini LM, Olmos PD, De Sousa GB (2003) Evaluation of a chromogenic medium for total coliforms and Escherichia coli determination in ready-to-eat foods. Food Microbiology 20: 601-604

8. Lindsay D, Von Holy A (1999) Different responses of planktonic and attached Bacillus subtilis and Pseudomonas fluorescens to sanitizer treatment. Journal of Food Protection 62: 368-379

9. Scott E, Bloomfield SF (1990) The survival and transfer of microbial contamination via cloths, hands and utensils. Journal of Applied Bacteriology 68: 271-278.

10. Jiang XP, Doyle MP (1999) Fate of Escherichia coli O157:H7 and Salmonella enteritidis on currency. Journal of Food Protection 62: 805-807.

11. Kusumaningrum HD, VnPutten MM, Rombouts FM, Beumer RR (2002) Effects of antibacterial dishwashing liquid on foodborne pathogens and competitive microorganisms in kitchen sponges. Journal of Food Protection 65: 61-65.

12. Ropkins K, Beck AJ (2000) Evaluation of worldwide approaches to the use of HACCP to control food safety. Trends in Food Science and Technology 11 10-21

13. Keeratipibul S, Techaruwichit $P$, Chaturongkasumrit $Y$ (2009) Contamination sources of coliforms in two different types of frozen ready-to-eat shrimps. Food Control 20: 289-293.
14. Iyer TSG, Shrivastava KP (1988) Incidence and low temperature survival of coagulase positive staphylococci in fishery products. Fishery Technology 25 : 132-138.

15. Hatha AAM, Paul N, Rao B (1998) Bacteriological quality of individually quick frozen (IQF) raw and cooked ready-to-eat shrimp produced from farm raised black tiger shrimp (Penaeus monodon). Food Microbiology 15: 177-183.

16. Prabakaran P, Sendeesh Kannan K, Anand M, Pradeepa V (2011) Microbiological quality assessment in a fish processing plant at Mandapam Ramanathapuram District. Archives of Applied Science Research 3: 135-138.

17. Rao KK, Lakshmanan PT, Agarwal A, Chakraborty R (1986) Raw materia supply to shrimp freezing plants: some significant aspects. Fishery Technology 23: $38-42$

18. Iyer TSG, Chaudhuri DR, Pillai VK (1970) Influence of season on the microbia quality of fresh and processed prawn. Fishery Technology 7: 93-94.

19. Reilly A, Dangula E, De La Cruz A (1986) Post harvest spoilage of shrimp (Penaeus monodon). Food and Agriculture Organization of the United Nations.

20. Zuberi R, Qadri RB (1992) Microbial flora of Karachi coastal water shrimp ( $P$ merguiensis) and role in shrimp quality deterioration. FAO Fisheries Report.

21. Jeyasekaran G, Karunasagar I (1996) Incidence of Listeria spp. in tropical fish International Journal of Food Microbiology 31: 333-340.

22. Food and Drug Administration (1992) Bacteriological Analytical Manual, (7thedn), Association of Official Analytical Chemists, Arlington, VA, USA.

23. Pérez-Rodríguez F, Valero A, Carrasco E, García-Gimeno RM, Zurera G (2008) Understanding and modeling bacterial transfer to foods: A review. Trends in Food Science and Technology 19: 131-144.

24. World Health Organization (1992) WHO surveillance programme for control of foodborne infections and intoxications in Europe. Sixth report Geneva, Switzerland.

25. Chen Y, Jackson KM, Chea FP, Schaffner D (2001) Quantification and variability analysis of bacterial cross-contamination rates in common food service tasks. Journal of Food Protection 64: 72-80.

26. ICMSF (1986) Microorganisms in Foods 2 Sampling for Microbiologica Analysis: Principles and Specific Applications. (2nd Edition) University of Toronto Press, Toronto.

27. ICMSF (1988) Microorganisms in foods 4: Application of hazard analysis critical point (HACCP) system to ensure microbiological safety and quality International Commission on Microbiological Specifications for Foods, Blackwell publishing, London.

28. EIC (1995) Manual of analytical methods for fish and fishery products. Export Inspection Council, Ministry of Commerce, Government of India, New Delhi.

29. EIC (1995) Export of fresh, frozen and processed fish and fishery products (Quality Control, Inspection and Monitoring) Order and Rules. Export Inspection Council, Ministry of Commerce, Government of India, New Delhi.

30. Vanderzant C, Mroz E, Nickelson R (1970) Microbial flora of Gulf of Mexico and pond shrimp. Journal of Milk and Food Technology 33: 346-350.

31. Zuberi R, Shamshad S, Qadri RB (1987) Effect of elevated temperature of storage on the bacteriological quality of tropical shrimp (Penaeus merguiensis). Pakistan Journal of Science and Industrial Research 30: 695-699.

32. Thampuran M, Gopakumar K (1990) Impact of handling practices on the microbial quality of shrimp (Metapenaeus dobsoni). FAO Fisheries Report.

33. Karunasagar I, Ismail SM, Amarnath HV, Karunasagar I (1992) Bacteriology of tropical shrimp and marine sediments. FAO Fisheries Report.

34. Iyer TSG, Joseph J (1995) Quality of cultured prawns. Export Inspection Journal 11: 15- 17

35. Antony MM, Jeyasekaran G, Shakila RJ, Shanmugam SA (2002) Microbiologica quality of raw shrimps processed in seafood processing plants of Tuticorin Tamil Nadu, India. Asian Fisheries Science 15: 33.

36. Jeyasekaran G, Karunasagar I, Karunasagar I (1990) Validity of faecal coliform test in tropical fishery products. Food and Agriculture Organization of the United Nations.

37. Varma PRG, Iyer TSG, Joseph MA, Zacharia S (1989) Studies on the incidence of $V$. cholerae in fishery products. Journal of Food Science and Technology 26: 341-342. 
Citation: Mandal B, Dubey SK, Bhattacharya D, Chand BK (2015) Significance of Cross-contamination on Bacteriological Quality of Black Tiger Shrimp (Penaeus monodon Fabricius 1798) for Export Trade Produced in Fish Processing Plant. J Aquac Res Development 6: 381. doi:10.4172/2155-9546.1000381

Page 5 of 5

38. Chen HC, Moddy MW, Jiang S (1990) Changes in biochemical and bacteriological quality of grass prawn during transportation by icing and oxygenating. Journal of Food Science 55: 670-673.

39. Dalsgaard A, Huss HH, Kittikurt AH, Larsen JL (1995) Prevalence of V. cholera and Salmonella in a major shrimp production area in Thailand. International Journal of Food Microbiology 28: 101-113

40. Varma PRG, Mathan C, Mathew A (1985) Bacteriological quality of frozen seafood for export with special reference to Salmonella. In: Proceedings of Harvest and Post-harvest technology of fish, Ravindran K, Unnikrishnan Nair N, Perigreen PA, Mathavan P, Gopalakrishna Pillai AG (Eds.), Society of Fisheries Technologists. Cochin, India. 665-667.

41. Bhaskar N, Rudra Setty TM, Reddy VSG, Manoj YB, Anantha CS, et al. (1995) Incidence of Salmonella in cultured shrimp, P. monodon. Aquaculture 138: 257266.

42. Food Standards Australia New Zealand (2001). Guidelines for microbiological examination of ready-to-eat foods.
43. Manoj YB, Rosalind GM, Karunasagar I (1991) Listeria spp. in fish and handling areas, Mangalore, India. Asian Fisheries Science 4: 119-122.

44. Kamat AA, Nair PM (1994) Incidence of Listeria species in Indian seafoods and meat. Journal of Food Safety 14: 117-130.

45. Garret ES (1988) Microbiological standards, guidelines, specifications and inspection of seafood products. Food Technology 42: 90-93.

46. Philips FA, Peeler JT (1972) Bacteriological quality of blue crab industry. Applied Microbiology 24: 958-966.

47. Duran AP, Wentz BA, Lanier JM, MacClure FD, Schwab AH, et al. (1983) Microbiological quality of breaded shrimp during processing. Journal of Food Protection 46: 940-1006

48. Eyles MJ (1986) Microbiological hazards associated with fishery products CSIRO Food Research Quarterly 46: 8-16.

49. Bloomfield SF, Scott E (1997) Cross-contamination and infection in the domestic environment and the role of chemical disinfectants. Journal of Applied Microbiology 83: 1-9. 